\title{
Mud cloth from Mali: its making and use
}

\author{
Elsje S Toerien
}

\section{OPSOMMING}

Bogolanfini van Mali, beter bekend as mud cloth, het in die laaste aantal jare bekendheid verwerf en daarby ook baie gewild geraak.

Vir baie jare was dit nie duidelik hoe hierdie kleedstof gemaak is nie. Dit was algemeen aanvaar dat die ontwerpe deur ' $n$ bleikingsproses verkry is. Vandag is dit bekend dat die ligte ontwerpe verkry word deur hulle met donker modder te omlyn en daarna die agtergrond in te vul. Afgesien van bogolanfini se dekoratiewe waarde, het die verskillende motiewe ook simboliese waarde, en word verskillende kombinasies gebruik om 'n geskiedkundige gebeurtenis te herdenk of 'n plaaslike held te vereer.

In hierdie artikel word daar gekyk na die tegnieke wat gebruik word om bogolanfini te maak, na die betekenis van sommige motiewe, en die verskillende maniere waarop die tegnieke of motiewe gebruik word. Die redes vir die verhoogde belangstelling in, en vervaardiging van bogolanfini word ook aangespreek.

\section{- Dr ES Toerien}

Department of Community Resource Technology VUDEC

Vista University

\section{INTRODUCTION}

The stark, geometric, black and white designs traditionally found on the mud cloths from Mali, can today be found on everything from clothing and furniture to book covers and wrapping paper. Along with kente (from Ghana), mud cloth has become one of the bestknown African cloth traditions worldwide (Clarke, 2001). Luke-Boone (2001:8) describes it as 'probably the most influential ethnic fabric of the 1990's'. The designs have indeed become an important part of the modern ethnic look found in African-inspired fashions today.

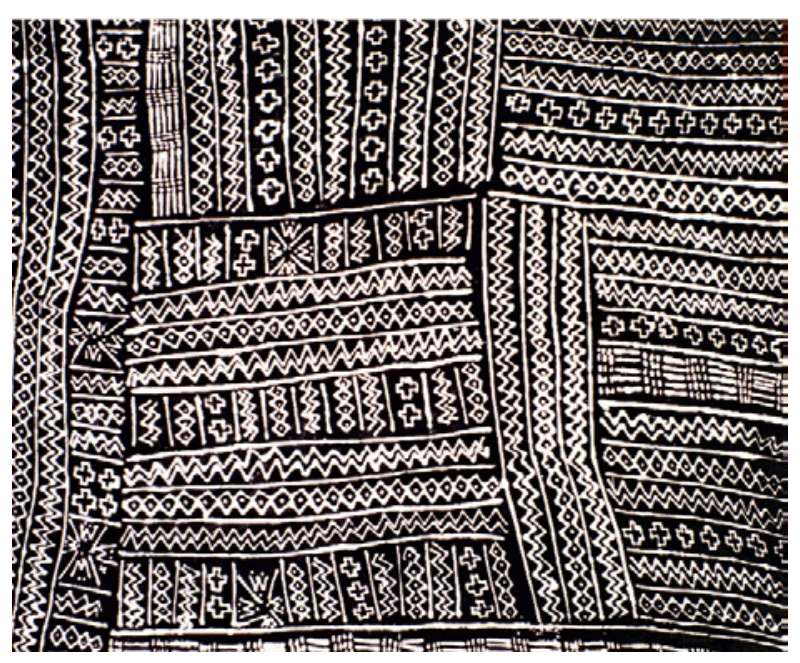

FIGURE 1: $\quad$ MUD CLOTH WITH TYPICAL

DESIGN (Photo: T van Eeden)

\section{THE NAME AND ORIGIN OF MUD CLOTH}

The Malian mud cloth is frequently referred to as bogolanfini or bokolanfini. The word bogolan means something made by using mud, while fini means cloth (Rovine, 1997).The Bamana, who live to the east and north of Bamako traditionally made the cloth. The best work is done in the Beledougou area. It is also thought that the work originated here (Polakoff, 1982:131; Imperato, 1994).

Luke-Boone (2001:8) claims that the dyes and fabric used in mud cloth can be traced back to the 12th century AD. Due to the perishable nature of fabric and the humid climate of tropical sub-Saharan Africa, it is very difficult to do research on and document African textiles (Polakoff, 1982:11). However, excavations of archaeological deposits in caves in the Bandiagara area of Mali have proved the existence of a large cotton industry as early as the 11 th century AD (Picton \& Mack, 1989:31). Some of the designs frequently used 
on mud cloth depict historical events of the 19th century (Polakoff, 1982:146). It can therefore be assumed that the techniques used in the making of mud cloth, if not dating back to the 12th century, have been used for a long time.

\section{THE FALL AND RISE OF MUD CLOTH}

Due to the symbolic nature of the mud cloth designs, and the use of these designs during significant events in traditional Bamana life, it can be postulated that these played an important role in Malian society. Unfortunately colonial Africa developed a taste for the cheap, machine produced fabrics worn by the European rulers. These imported fabrics were seen as being prestigious, and indicating status and a high social position. Missionaries 'were busy converting Africans not only to Christianity but to Western clothing as well' (Polakoff, 1982:5). In 1970 Imperato and Shamir pointed out that unless new interest and a demand for mud cloth can be generated, it would not survive beyond the next few decades. In their authoritative book on African textiles (first published in 1979) Picton and Mack (1989:161) devote only one paragraph to mud cloth.

As the winds of change blew over Africa, and more and more African countries achieved independence, an interest in traditional textiles grew with a sense of national pride. Social and political developments in the United States of America also caused an interest in African textiles. The 'back to your roots' movement sent young black Americans to Africa in search of their cultural identity. The popularity of mud-cloth designs increased dramatically when in 1979, Chris Seydou, a Malian fashion designer based in Paris, included a bogolan wrap in his winter collection (Adire African Textiles, 1999; Luke-Boone, 2001:11). He continued the use of the fabric through the 1980's until his early death in 1994. He also helped Malian textile factories to develop industrially manufactured versions of mud-cloth designs.

Since 1990 changing economic and political circumstances have led to the vastly increased production and consumption of bogolan in Mali. This will be discussed at a below.

\section{THE MAKING OF MUD CLOTH}

For many years much confusion existed on how mud cloth was made. It was generally considered that the designs were produced by a discharge method, that is, the fabric is first dyed in black and the light patterns then achieved by bleaching. Picton and Mack (1989:161) still refer to it as a 'discharged-dyed' textile, although their description of how it is made is correct. Thanks to the work done by Imperato and Shamir (1970) it is now known that the light designs are achieved by outlining them in black and then painting in the black background.
The most detailed description of how mud cloth is made can be found in Polakoff (1982:135) and Imperato and Shamir (1970), but most works on mud cloth (Picton \& Mack, 1989:161; Rovine, 1997; Clarke, 2001; Luke-Boone, 2001:9; AfroDecor, 2002) contain similar information. Unless otherwise indicated, the account below is a synthesis of the above-mentioned descriptions:

- Locally produced cotton is combed and spun into yarn by women.

- The yarn is woven on a double-heddle loom into a narrow strip of about $15 \mathrm{~cm}$ in width. In West Africa men almost exclusively use the double-heddle strip loom. Adler and Barnard (1992:30) say that strip weaving 'must be the most labour-intensive weaving, per square inch of produced cloth, known to man'. They attribute the popularity of this type of weaving to the fact that the loom can easily be dismantled and transported, and that it requires a very small capital investment. (See Picton \& Mack (1989) for a detailed description of looms used in Africa.)

- The strip is cut into shorter pieces, the length of the required final cloth. These strips are then joined selvedge to selvedge with a whipstitch.

- The cloth is washed (mainly to preshrink it) and dried in the sun. This white cloth is called finimougou and is used extensively for clothing in this undecorated state.

- The leaves and branches of two different trees, N'Galaman (Anogeissus leiocarpus) and N'Tjankara (Combretum glutinosum), are pounded and soaked in water for 24 hours or boiled in water for a few minutes. This forms a brownish tea, rich in tannic acid.

- The cloth is soaked in this solution and takes on a deep yellow colour. The yellow substance acts as a mordant. The cloth is spread out to dry in the sun.

- The painting is done with mud that has been collected from ponds the previous season and left to ferment. The artist outlines the designs with a piece of bamboo or metal tool dipped in the mud. The background surrounding the designs is also filled in with the mud.

- As the cloth is left to dry, the dark black turns grey. The cloth is then washed to remove excess mud.

- The process of soaking in the leaf tea, painting with mud, washing and drying is repeated a second and sometimes a third time. With each application the mud painted areas become darker.

- The yellow areas are then painted with bleach made from boiled, ground peanuts, water, caustic soda and millet bran. This turns the yellow patterns brown.

- The cloth is placed in the sun for a week, after which the bleach solution is washed off with water. This leaves the characteristic white patterns on the dark background.

This whole process can take several weeks to complete. The yellow, although it cannot be seen in the final product, forms a very important part of the whole process. The iron oxide in the mud is converted to iron 
tannate by the tannic acid in the leaf tea. The tannic oxide forms a fast dye, which will lighten only slightly with subsequent washings.

Traditionally, the whole painting process was only done by women. Young women were taught by their mothers during a long-term apprenticeship. As with most West-African textile production, all the different activities in the making of mud cloth (spinning, weaving and decoration) have always been clearly gender defined. Lately young men have also taken up the task of painting cloths, most of it aimed at the tourist market.

In the area near Mopti and Djenne, artists generally considered to be less skilled produce cloth by painting black designs on yellow cloth. The yellow is obtained by dyeing the cloth in wolo, a solution made from the leaves of Terminalie auicennoides. The wolo is removed, leaving black designs on a white background. The white areas are frequently dyed a deep orange using a solution from the bark of M'Peku (Lannea velutina). The artists from Beledougou consider these cloths to be of inferior quality (Polakoff, 1982:134). Rovine (1997) remarks that such simplification is now widespread, and not the result of a lack of skill, but caused more by a need to produce large quantities of cloth over a short period.

\section{MEANING OF MUD-CLOTH DESIGNS}

In addition to being highly decorative, the different designs or patterns found on mud cloth have symbolic meanings. The knowledge of the symbolic meanings behind these designs is handed from mother to daughter during their apprenticeship. The designs are usually abstract or semi-abstract representations of everyday objects. These designs are used together to represent a historical event or commemorate a local hero (Imperato \& Shamir, 1970; Polakoff, 1982: 145). One such combination of designs is called Samory Ani Tieba Benyero, and tells the story of the battle between Tieba, a 19th century king and Samory, a warrior. Another honours Koumi Diosse, a hero from Beledougou, who led a revolt against the French in 1915. Meanings attached to designs may differ depending on region or ethnic group (AfroDecor, 2002). Below are a couple of the designs with their meanings (Imperato \& Shamir, 1970; Polakoff, 1982:147; LukeBoone, 2001: 12; AfroDecor, 2002).

Traditionally these patterns were arranged in different design fields. If a cloth were made to be worn as a woman's wrapper, the design fields would be distinctly horizontal. The cloth would have an identifiable top and bottom and be divided into five different fields. The central field would be the largest and most complex. It would be framed by narrower strips on all four sides. The left, right and bottom strips usually are of the same width and complexity, while the top strip would be much narrower, often containing a repetition of only one symbol (Arnoldi, 2000). Mud cloths made for the tourist market are often greatly simplified. They contain no clear horizontal orientation and no top and bottom. The designs themselves are also more simple (Arnoldi, 2000). Not everyone approves of this simplification. A well-known bogolanfini artist is quoted as having said: 'They are nonsense'. Rovine (1997) points out that this is immaterial, those buying these cloths are mostly non-Malian, and would not understand the meaning anyway. She says: 'That the patterns might have specific meanings is, for the most, an interesting detail that adds to the cloth's exoticism'. Mud cloth is beautiful enough to provide pleasure without understanding its symbolic meaning (AfroDecor, 2002).

\section{USES OF MUD CLOTH AND MUD-CLOTH DESIGNS}

\section{Traditional}

Mud cloth was used mainly for making hunters' shirts or tunics and women's wraparounds (Polakoff, 1982:144). A woman would wear these cloths during important transitional periods in her life: after excision, prior to the consummation of her marriage, immediately following childbirth, and finally as a burial shroud (Rovine, 1997).

\section{Modern}

According to Rovine (1997) there are three different ways in which the techniques or designs of mud cloth are used today, while Arnoldi (2000) adds a fourth. These new forms are referred to as bogolan, and while retaining some of the characteristics of traditional bogolanfini, they are clearly not the same.

Tourist-Market Bogolan Large quantities of cloth are made purely to be sold on the tourist markets or are for export. These cloths are still painted on stripcloth, an indication to the consumer that the cloth has been woven and decorated by hand and not merely churned out in a factory. As indicated earlier, the designs are simplified and not organised in different design fields any more. The designs are frequently painted in black on a yellow or orange background. Stencils made from cardboard or plastic are also used. These stencilled cloths can be monotonous as it allows for little individual variety. According to Rovine (1997) these stencilled designs are unrelated to traditional mud cloth designs and depict village scenes and dancers. An artist can produce six to seven times the number of cloths using these new methods in comparison with the old ones.

The increased production of commercial mud cloth can partly be attributed to certain political and economic events. Up to 1991 students could pay their living expenses out of scholarships provided by the government. They were also reasonably sure of a job in government after graduation. In 1991 a coup d'état overthrew the dictator Moussa Traore and a multiparty, democratic political system was established. The number and size of scholarships were significantly reduced, and many young graduates became unemployed. They saw the renewed interest in mud 
cloth as an entrepreneurial opportunity. The long apprenticeships were replaced by short, informal training sessions. In contrast to the traditional custom, it was now young men, and not women, who produced mud cloth. This may perhaps be attributed to the fact that men find it easier to obtain capital to purchase materials and are also less restricted by home and family responsibilities.

It is most likely that a large percentage of mud cloth sold on craft markets in South Africa was made in San, a city northeast of Bamako (see map, figure 2). As early as 1977 it was reported that there are 'people of all generations happily devoting themselves to this art" (Berthe \& Konate, in Rovine, 1997). The cloths from San are characterised by stark white patterns against a deep black background. Luke-Boone (2001:11) also states that San is the centre of mudcloth production at present and the source of the highest quality cloth. Figure 4 is an example of such tourist market cloths sold in South Africa today.

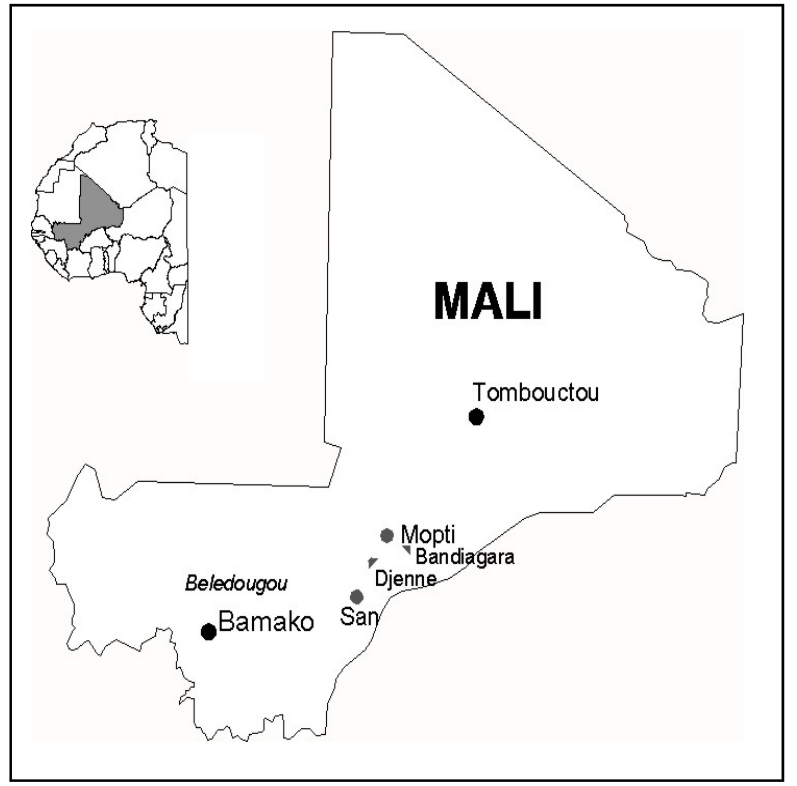

FIGURE 2:

\section{MAP OF MALI}

Fine-art Bogolan A number of Malian artists produce bogolan as a form of fine art. The Groupe Bogolan Kasobané consists of six artists that have been working together since 1978. They stretch the cloth and hang it out like a canvas. The painting is produced with vegetable dyes and mud, but the designs are often not related to those of bogolanfini. These paintings are mostly bought by expatriates and nonMalians such as diplomats, development workers or tourists. (See Rovine, 1997 and Goldner \& Dembele, 1999 for a more detailed description of fine-art bogolan and the work of the Groupe Bogolan Kasobané.)

Bogolan Clothing A differentiation can be made between two distinct types of bogolan clothing. The first group makes use of traditional African garments, mostly boubous (long, widesleeved robes worn by both men and women). The bogolan designs are placed on those areas that are usually embroidered, around the neckline and down the front, but the motifs used differ from those on traditional cloth. This type of clothing was originated by the Groupe Bogolan Kasobané. The group wishes to preserve the knowledge of bogolanfini techniques, and continues to research the bogolan traditions in rural settings, collecting vegetal and mineral substances to be used as dyes. Rovine (1997) says of their work that 'while this bogolan bears little or no formal resemblance to the traditional cloth that was its inspiration, it is more an elaboration of an existing tradition than a separate entity'.

In contrast with this is the work of Chris Seydou. Seydou was not interested in how the cloth was produced and did not make it himself. He used cloth that he bought in the market or had painted by artists, to produce garments that were European in style, miniskirts and jackets, rather than boubous. The designs, although simplified, look far more like those on traditional mud cloth than do the designs on the work of the Groupe. Seydou felt that traditional bogolanfini had too many patterns, and were visually too complex to be used for European-styled clothing. The meaning of the designs were unimportant to him, he was purely interested in their graphic quality (Rovine, 1997; LukeBoone, 2001:11; African Voices, 2002).

Commercial Adaptations Bogolan designs are seen on a wide variety of commercial products, from coffee mugs, curtaining, towels and sheets, to book covers and wrapping paper (Arnoldi: 2000).

\section{THE CONTINUED PRODUCTION AND USE OF BOGOLANFINI}

As with many other ethnic textiles, one may conjecture about the reasons for the continued production and use of mud cloth. As for the production, the reason is obvious, as since the early 1990's the cloth has become so popular that it is a source of income for otherwise unemployed people. Toerien (1994) states that it is not only the availability of cheaper, factoryproduced textiles that influences the production of handcrafted cloth in Africa, but that the social and political systems and continued changes also play a role. Mud cloth's popularity among Malians, Malian expatriates, and African Americans can perhaps be attributed to its 'African connection'. But it is also found in the homes of people who have no idea where the cloth comes from, or where Mali is, and are totally ignorant about the fascinating technique used to produce the cloth, and the meanings behind motifs. This can perhaps be ascribed to the absolute versatility of the cloth, equally at home in traditional and modern settings, and the highly decorative quality of the designs, simple on their own, yet complex in their combination.

However, nothing remains in fashion forever, and the question is whether the young men from Mali will continue to produce mud cloth once its popularity declines. It is unlikely. Barber (1991:293) argues that women have always enjoyed making patterned tex- 
tiles for the delight and enjoyment of creating something, but that the delight is reduced once the process becomes too efficient and economical:

If you need to make an object anyway such as clothes, towels, rugs, - may as well make something you enjoy making, enjoy looking at, enjoy using. The shift from such an atttude of enjoyment to one of efficiency has often been remarked upon ... the elaborate and exquisite early decorations were suddenly reduced to the simple and humdrum, i.e., the mass-produced.

To what extent can the cloths produced by young men for the tourist trade be seen as 'mass-produced'? Will they stop producing mud cloth once it is not so profitable? And will the rural women continue to produce mud cloth, not only out of necessity, but more because of the delight of the creative process and the social interaction embedded in it? Only time will tell.

\section{REFERENCES}

ADIRE AFRICAN TEXTILES. 1999. Bogolanfini introduction. Available online. URL: http://www.adire.clara.net/bogolanfinitext2.html Accessed 10 March 2003.

ADLER, P \& BARNARD, N. 1992. African majesty. London. Thames \& Hudson.

AFRICAN VOICES. 2002. Chris Seydou: Malian fashion designer (1949-1994). Available online. URL: http://rit.edu/ africa/bamana. Accessed 30 April 2003.
AFRODECOR. 2002. Mud cloth meanings. Available online. URL: http://afrodecor.com.html. Accessed 10 March 2003.

ARNOLDI, MJ. 2000. Renewing tradition the revitalization of bogolanfini in Mali and abroad. African Arts. 33(3). Available online. URL: http://web12.epnet.com. Accessed 11 March 2003.

BARBER, EJW. 1991. Prehistoric textiles. Princeton. Princeton University Press.

CLARKE, D. 2001. The process of making bogolanfini or mud cloth. Available online. URL: http://ltpwww.gsfc.nasa.gov/globe/bogolan/bogolan.ht $\mathrm{ml}$. Accessed 10 March 2003.

GOLDNER, J \& DEMBELE, K. 1999. The Group Bogolan Kasobané. Available online. http://www.uiowa.edu/ africart/toc/contemporary/grou pe1.html. Accessed 9 May 2003.

IMPERATO, PJ 1994. Nakunte Diarra: Bogolanfini artist of the Beledougou. African Arts. 27(2). Available online. URL: http:/web15.epnet.com. Accessed 22 April 2003.

IMPERATO, PJ \& SHAMIR, M. 1970. Bokolanfini: Mudcloth of the Bamana of Mali. African Arts 3(4):3242.

LUKE-BOONE, R. 2001. African fabrics. lola. Krause. PICTON, J \& MACK, J. 1989. African textiles. London. British Museum Press.

POLAKOFF, C. 1982. African textiles and dyeing techniques. London. Routledge \& Kegan Paul.

ROVINE, V. 1997. Bogolanfini in Bamako. African Arts. 30(1):40-55

TOERIEN, ES 1994. Possible social and political reasons for the continued production of Bakuba cut-pile cloth. Journal of Dietetics and Home Economics. 22(2):116-118. 